\title{
THE MEDIA MYTH CREATION IN THE ANTHROPOCENTRIC DIMENSION (THE ENGLISH SOCIAL AND POLITICAL DISCOURSE STUDIES)
}

\author{
O.V. Kulikova \\ Moscow State Institute of International Relations (University), \\ 119454, Moscow, Prospekt Vernadskogo, 76
}

\begin{abstract}
The paper considers linguistic and discursive features of anthropocentric myth creation in the social and political media. Myth creation in the social and political context is viewed as creation of social and political myths correlating with real and fictional events, public persons or social and political phenomena. The author brings into light the role of the media audience as one of the leading factors ensuring successful creation of the media mythological image appealing predominantly to the emotional sphere in the mass recipient's consciousness. Strange as it might seem, the anthropocentric mythological discourse demonstrates the minimal amount of explicit emotiveness, which creates conditions for independent evaluation of the information by the audience itself. Narrative is considered to be the basic myth creation format. It is represented as a series of stories about the myth creation object. Given the diachronic aspect of myth creation and its chronotope which can span quite a long period of time, it is suggested to speak of the narrative continuum focused on a media person who is in the centre of public attention. It is pointed out that media myth creation takes place on the basis of implications which appear in the process of reception of factual information by the media audience. The interaction of verbal and non-verbal means typical of the media fosters creation of a full-bodied anthroponymic mythological image, which calls for a special study.
\end{abstract}

Key Words: myth creation, myth, anthropocentrism, mass-media, socio-political discourse, narrative, narrative continuum, implications

\section{МЕДИЙНОЕ МИФОТВОРЧЕСТВО В АНТРОПОЦЕНТРИЧЕСКОМ ИЗМЕРЕНИИ (НА МАТЕРИАЛЕ АНГЛОЯЗЫЧНОГО ОБЩЕСТВЕННО-ПОЛИТИЧЕСКОГО ДИСКУРСА)}

\author{
О.В. Куликова
}

Московский государственный институт международных отношений МИД России (Москва, Россия), 119454 г. Москва, проспект Вернадского, 76 
Аннотация. Настоящая статья посвящена рассмотрению лингводискурсивных особенностей антропоиентрического мифотворчества в медийной среде общественно-политического дискурса. Мифотворчество в общественно-политическом контексте понимается как создание общественных или политических мифов, коррелирующих с реальными или вымышленными собьтиями, действующими тицами или явлениями общественно-политической жизни. Подчёркивается роль медийного адресата как одного из ведущих факторов успешного создания медийного мифообраза, апеллирующего преимущественно к сфере эмоционального в сознании массового рециичента. При этом медийный антропоцентрический дискурс демонстрирует минимум эксплицитной эмотивности, что создаёт условия для независимого формирования оценки аудиторией мифообразующей информации. Отмечается, что в качестве базового формата миботворчества в медийной среде выступает нарратив, представленный серией историй об объекте мифотворческой деятельности. Учитывая диахронический аспект создания мифообраза и его хронотоп, которьй может охватьвать довольно длительньй период, предлагается говорить о нарративном континууме, сконцентрированном на тичности медийной персоны, обычно пребывающей в иентре общественного внимания, - событиях жизни, происшествиях и поступках, создающих сложный рисунок антропонимического миба. Характерное для медийной среды взаимодействие вербальных и невербальных средств, обеспечиваюшее создание полноценного антропонимического мифообраза, должно послужить предметом отдельного исследования.

Ключевые слова: мифотворчество, миф, антропочентризм, масс-медиа, общественно-политический дискурс, нарратив, нарративный континуум

\section{Введение. Убеждающая коммуникация в СМИ}

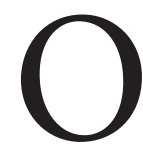
бщественно-политический процесс, воплощённый в общественно-политическом дискурсе, представляет собой своеобразную форму непрерывной многовекторной коммуникации, участниками которой являются различные политические и общественные институты, представители широкой общественности, масс медиа - от магната-владельца печатных изданий до рядовых сотрудников медиа - журналистов, аналитиков, PR-менеджеров, политтехнологов, политических психологов и прочих, большинство из которых представляют стороны, заинтересованные в оказании воздействия на общественное сознание. Таким образом, медиа, выполняя посредническую функцию в общественно-политическом дискурсе, ориентированы на массовую аудиторию и имеют целью, помимо распространения информации, убеждение, побуждение к действию и пробуждение намерения [4, с. 386]. Воздействие СМИ на человека определяется как «убеждающая коммуникация» $[8$, с. 81-82], способствующая формированию общественного мнения.

Убедительность, как особый психологический параметр, признаётся «важной характеристикой семантического аспекта в процессе коммуникации» [6, с. 181]. Убедительное сообщение легче воспринимается и лучше запоминается, так как такая информация, по утверждению А. Моля, становится частью сознания индивида, при этом с другой стороны, человеку всегда кажется убедительным то, что он хорошо запомнил. Данный принцип положен в основу пропагандистской деятельности масс медиа и воздействия прессы на массовое сознание.

А. Моль выделяет четыре степени воздействия сообщения на получателя и, соответственно, усвоения им сообщения: приём; пассивное запоминание; рассудочное признание убедительности содержащихся в сообщении доводов; «внедрение» сообщения в сознание получателя, основанное на воздействии на его логику и чувства [там же]. Последнее означает изменение структуры сознания реципиента в соответствии с полученным сообщением. Отмечая, что процессы убеждения не ограничиваются исключительно логическими формами, апеллирующими к рациональному 
в сознании массового реципиента, А. Моль подчёркивает, что «толпу убеждают не доводами, а эмоциями» $[6$, с. 182], при этом убеждение ориентировано на аксиологическую систему, сложившуюся в данном социуме. В масс медиа большинство сообщений направлено на воздействие на чувства получателя информации и ориентируется на его систему ценностей. Человек (потенциальный реципиент) с его мнением, взглядами, желаниями и интересами помещается в фокус профессиональной медийной деятельности, направленной на формирование картины мира индивида посредством отбора соответствующей информации и её интерпретации.

Настоящее исследование концентрируется на роли фактора медийного адресата в формировании антропонимического мифа в пространстве СМИ. В этой связи рассматриваются особенности антропоцентризма медийного мифотворчества, а также вопрос, связанный с выбором наиболее оптимального формата создания мифа в медийной среде. Исследование проходило в русле когнитивно-дискурсивной парадигмы с применением основ дискурс-анализа, элементов когнитивного и лингвостилистического анализа.

\section{1. Антропоцентризм медийного мифотворчества}

Согласно Е.С. Кубряковой, антропоцентризм, как один из основных принципов современной лингвистики, проявляется в том, что «человек становится точкой отсчёта в анализе тех или иных явлений, что он вовлечён в этот анализ, определяя его перспективу и конечные цели» $[5$, c. 212$]$. Рассмотрение особенностей процесса мифотворчества в медийном пространстве подтверждает данное положение. Отличительное свойство медийного мифологического дискурса - антропоцентрический дуализм: в дискурсе, ориентированном на человека как адресата, одно из главных мест также занимает человек, выступающий, как центральный элемент ведущих дискурсивных тактик, в качестве объекта внимания адресата. Прежде всего, это дискурс, ориентированный на получателя информации - коллективного реципиента, представленного широкой и разнообразной аудиторией, ценностные ориентиры и интересы которой определяют характер и тональность дискурса, а также выбор дискурсивных тактик, способных найти адекватный отклик у адресата.

Антропоцентризм мифологического медийного дискурса обусловливается его прагматикой, состоящей в том, чтобы заставить реципиента поверить в достоверность создаваемого мифообраза и убедить аудиторию принять объект мифотворчества таким, как его представляют источники в масс медиа. Вовлечённость реципиента в мифологический дискурс, позволяющая реализовать прагматический потенциал принципа антропоцентризма, обеспечивается обращением к системе ценностей адресата, служащей для него ориентиром и опорой в формировании собственной точки зрения в отношении объекта мифотворчества. То есть, речь идёт об оценочной интерпретации реципиентом полученной из медийных источников информации, в частности, медийного мифологического текста, являющегося «своего рода посредником между индивидом и реальностью, которую он призван представлять» [2, с. 104]. «Посредническая» роль масс медиа как динамической структуры, связывающей познание и реальность, отмечается и другими исследователями (см., например, [7]).

Представление реальности посредством мифотворчества - хорошо отработанная практика СМИ, использующими техники мифологизации для манипулирования массовым сознанием. Ю.В. Балахонская выделяет два способа создания политического мифа: стихийное возникновение и «целенаправленное распространение мифологических сюжетов для создания определённого настроения в обществе» [1, с. 189]. Именно второй способ является ответственным за превращение мифа в факт общественного сознания.

Мифотворчество создаёт так называемую «вторичную реальность» [3], что подтверждается мнением Е.И. Шейгал, считающей (со ссылкой на А.Н. Савельева), что «политический мир изначально - всегда выдумка, вслед за которой у мифотворца и мифопотребителя может возникать ощущение реальности» (цит. по [10, с. 137]). Исследование связей политического мифа с идеологией, насаждающей определённую систему ценностей, приводит автора к выводу о роли мифа в 
порождении «иллюзии реальности с целью интерпретации в желательном [для его создателей] направлении» [там же, с. 138].

Создание мифа в медийной среде, если речь идёт о реальном персонаже, имеет ряд особенностей, главная среди которых - опора на реальные факты, события, истории. Исследователи речевого воздействия в СМИ указывают на зависимость формирования образов сознания индивидов от «регулярно и целенаправленно продуцируемых медиаобразов» [2, с. 104; 9], в большинстве своём репрезентированных в медиадискурсе мифологемами-антропонимами ${ }^{1}-$ именами известных личностей - политиков, общественных деятелей, представителей бизнеса, науки, культурной сферы и т.П., хорошо известных широкой общественности и имеющих ценностную значимость для её представителей.

Обращение к известной тичности, события жизни которой связаны с историей страны, её общественно-политическим развитием, экономическим преуспеванием, научными и культурными достижениями, служит проявлением антропоцентризма в медийном мифологическом дискурсе. Обычно такая личность находится в центре общественного внимания и привлекает интерес публики, стремящейся получить максимум информации, что отвечает намерениям создателей мифообразов, подающих информацию в интерпретации, способствующей формированию задуманного имиджа.

\section{2. Нарративный континуум как медийный формат создания мифообраза}

В этой связи возникает вопрос о медийном формате, позволяющем конструировать мифообраз, стимулирующий интерес публики и стремление подражать, отличающийся достоверностью и вызывающий доверие к источнику информации.

Традиционно формат понимается как продуманная медиастратегия в отношении репрезентации определённой темы, своего рода сценарий, по которому происходит развёртывание коммуникативного процесса [7, с. 150]. В целом принимая предложенное значение термина «формат» как «формы построения и подачи информации» [7, с. 151], в своей работе мы используем его для обозначения дискурсивной структуры, подразумевающей интеграцию различных медийных жанров, в результате чего создаётся объёмный мифообраз, воплощающий моральные качества и базовые ценности, способные вызвать положительный отклик медийной аудитории. В масс-медийном общественно-политическом дискурсе к структурам подобного рода принадлежит нарратив, точнее, нарративный континуум, строящийся на тематической связи между произведениями разных жанров, составляющих повествование о персонаже, что соответствует его статусу как формата медиапамяти. Нарратив отражает антропоцентрические установки медийного мифодискурса: как считают исследователи-нарратологи, нарратив сконцентрирован на человеке и его действиях, а происходящие с ним события являются значимыми прежде всего для его внутреннего мира - его убеждений, желаний, ценностей, идей и т.д. [12, с. 46]. Аналогичной точки зрения придерживается В. Шмид, утверждающий, что «любой внешний или внутренний поступок связан с определённым внутренним движением, сознательным или бессознательным» [11 URL]. Нарратив как конвенциональная форма изложения органично воспринимается реципиентом, так как сознание человека организует воспоминания о прошедших событиях преимущественно в форме нарратива - последовательности прошлых историй, объяснений, оправданий своих или чьих-то поступков и т.д. Цель нарратива - не точность передачи произошедшего, но правдоподобность, что особенно важно при создании общественно-политического мифа. Таким образом, нарратив - это одна из возможных версий реальности, создаваемая на основе предъявляемых к нему конвенциональных требований, однако не верифицируемая и не поддающаяся строгим логическим процедурам. По замечанию Дж. Брунера, критерием «правдивости» нарратива выступает не его верифицируемость, а его правдоподобность [12, с. 51].

\footnotetext{
1 подробнее о мифологемах-антропонимах см. [10].
} 
Нарратив мифологического дискурса в медийной среде формируется по модели дискурса, предложенной Чейфом (The Flow Model of Discourse), согласно которой развёртывание дискурса происходит как движение от фокуса к фокусу, от мысли к мысли. Границы эпизодов в нарративном дискурсе обозначаются сменой места или времени действия, изменениями в событийной структуре, в расстановке действующих лиц и т.п. [13]. В. Лабов выделяет два компонента нарративной структуры, подлежащие рассмотрению с позиций лингвистики - что произошло и почему об этом стоит рассказывать [14]. События, представленные в эпизодах нарратива, составляющих элементы его структуры, должны быть релевантными для всего нарративного континуума, что особенно верно в случае создания медийного мифа.

\section{3. Ключевые характеристики нарративного континуума как формата медийного мифотворчества: storytelling, диахроничность, эффект медийного присутствия}

Минимальной повествовательной единицей в нарративном континууме является история. В процессе медийного мифотворчества особое значение приобретает когнитивно-психологический аспект storytelling, включающий активизацию внимания реципиента, запоминание им предъявляемой информации, возможность пересказать историю другому человеку, сравнить полученную информацию с собственным опытом. Участвуя в процессе storytelling, человек постигает суть коммуникации.

Применительно к общественно-политической коммуникации storytelling рассматривается нами как часть коммуникативного процесса, протекающего в рамках медийного мифологического дискурса.

Технология storytelling обеспечивает возможность интерпретации реципиентом получаемой информации, для чего её отправитель должен спрогнозировать вероятную реакцию адресата и использовать адекватные языковые средства для вербального оформления создаваемого мифа. Прогнозирование реакции медийной аудитории происходит на основе понимания отправителя информации того, что представляют собой фоновые знания коллективного реципиента.

Нарратив мифологического медийного дискурса строится вокруг так называемой «медийной личности», всегда находящейся на виду и играющей важную роль в общественно-политической жизни социума. Безусловно, к таким медийным персонам относится королева Великобритании Елизавета II, на протяжении долгих лет поддерживающая миф о британской монархии.

В исследовании особенностей политической мифологии М.В. Балахонская ссылается на воззрения Э. Дюркгейма, рассматривавшего мифы как полезные аллегории, роль которых заключается в «создании механизма адаптации к меняющемуся обществу» [1, с. 193]. Миф о британской монархии - своего рода возможность адаптироваться к меняющемуся миру через идею сохранения стабильности, незыблемости устоев и ценностей. Британская монархия как существующая форма правления, как реальное явление современной общественно-политической жизни страны сама по себе не является объектом создаваемых мифов, однако представление о британской монархии как о наиболее приемлемом для британцев государственном устройстве поддерживается благодаря созданию стойкого мифообраза центральной фигуры, обладающей верховной властью, - королевы Великобритании.

Исследователи-нарратологи обращают внимание на такую характеристику нарратива, как его диахроничность: нарратив (применительно к мифотворческому процессу - нарративный континуум) - это повествование о событиях, происходивших на протяжении некоторого отрезка

времени. Лексические единицы, репрезентирующие такие события (или серии событий), но не несущие в своей семантике семы темпоральности (например, «трагедия» или «фарс»), по сути подразумевают определённую модель, в соответствии с которой событийная цепочка развёртывается во времени [11, p. 46].

Диахрония мифообраза Елизаветы II, то есть своеобразный непрерывный нарратив о королеве на протяжении длительного времени, начиная с детских лет и до наших дней, позволяет создать у аудитории ощущение неразрывности связи времен, устойчивости монархии, 
стабильности жизненного уклада британцев и неизменности их национально-культурных ценностей.

Следующий материал со страницы электронной версии газеты Independent, посвящённой королеве Елизавете II, представляет собой квинтэссенцию нарративного континуума, в котором заложена идея незыблемости британских традиций и ценностей сквозь призму отношения к ним одного персонажа - королевы Елизаветы II - на протяжении периода с мая 1945 года до сегодняшнего дня. Речь идёт о праздновании Дня победы (окончания войны в Европе) и об отношении к этому событию королевы Великобритании - в юности и сегодня. Поэтому не случайно материалу предпосланы два заголовка:

\section{The Queen: How Princess Elizabeth celebrated VE Day unnoticed among the crowds on the streets of London}

The Queen is to make a special televised address to mark 75th anniversary of VE Day

Sunday 14 June 2020 07:20

On 8 May 1945, the world rejoiced as the Second World War came to an end after six years of fighting, hardship and loss.

People took to the streets to celebrate VE Day, otherwise known as Victory in Europe Day, commemorating the day on which the allied forces announced the surrender of Nazi Germany.

In London, thousands of revellers flooded Trafalgar Square and the Mall leading up to Buckingham Palace where the King and Queen greeted them from the balcony.

Unbeknownst to the majority of the public, 19-year-old Princess Elizabeth and 14-year-old Princess Margaret were hidden in plain sight among the crowds, letting their hair down as they joined in with the jubilant festivities.

This year, Friday 8 May will mark the 75th anniversary of VE Day.

Queen Elizabeth II, who recently celebrated her 94th birthday, will make a special televised address to the nation, which will be broadcast on $\mathrm{BBC}$ One, aired on the radio and the royal family's official social media channels.

The address will be aired at 9pm, the same time the Queen's father, King George VI, announced victory in Europe on the radio in 1945 following "nearly six years of suffering and peril".

\section{How did Princess Elizabeth and Princess Margaret celebrate VE Day in 1945?}

On VE Day 75 years ago, Princess Elizabeth and Princess Margaret appeared on the Buckingham Palace balcony on six occasions throughout the day alongside their parents King George VI and Queen Elizabeth.

However, the teenagers wished to also celebrate outside the Palace gates, which they did after the younger of the two proposed the idea.

After dinner, the princesses left the Palace to partake in the celebrations, with the permission of the King and Queen.

They were joined by a group of Guards officers who were friends with the young royals.

While the monarch may have felt worried about his daughters becoming immersed in the crowds, in a diary entry written on the day he expressed care for their limited social lives, stating: "Poor darlings, they have never had any fun yet."

The princesses made the most of their freedom, doing the hokey cokey, the "Lambeth Walk" and the conga with members of the public ${ }^{2}$ (The Queen).

$\langle\ldots\rangle$ Princess Elizabeth wore her Auxiliary Transport Service uniform on VE Day, joined the armed forces in February that year.

The monarch told the BBC in 1985 that she tried to avoid being spotted on the streets of the capital, stating: "I pulled my uniform cap well down over my eyes".

\footnotetext{
2 Sabrina Barr. The Queen: How Princess Elizabeth celebrated the VE Day unnoticed among the crowds on the streets of London. Цит. по https:// www.independent.co.uk/life-style/royal-family/queen-elizabeth-ve-day-75-princess-margaret-celebrate-london-crowds-king-a 9490676 .html (дата публикации 14.06.2020; дата обращения: 15.08.2020). (Здесь и далее - The Queen).
} 
I remember lines of unknown people linking arms and walking down Whitehall, and all of us were swept along by tides of happiness and relief," the Queen said (The Queen).

Данный фрагмент нарратива наполнен множеством деталей, позволяющих «приблизить» описываемое событие и создающих запоминающийся образ в сознании реципиента (Unbeknownst to the majority of the public, 19-year-old Princess Elizabeth and 14-year-old Princess Margaret were hidden in plain sight among the crowds, letting their hair down as they joined in with the jubilant festivities; Princess Elizabeth and Princess Margaret appeared on the Buckingham Palace balcony on six occasions throughout the day alongside their parents King George VI and Queen Elizabeth; After dinner, the princesses left the Palace to partake in the celebrations, with the permission of the King and Queen (The Queen) и т.д.).

Эффект «наведения фокуса» на событие и его участников дополняется чередованием временных планов - рассказ о праздновании Дня победы в 1945 году перебивается сообщением о предстоящей речи королевы по случаю юбилейной даты, что возвращает читателя в настоящее время, и завершается цитатой из воспоминаний Елизаветы II о том памятном дне 1945 года, коррелирующей с началом повествования. Использование в нарративе прямой речи участника события (см. заключительные абзацы текста) усиливает впечатление достоверности создаваемого мифообраза и вызывает расположение аудитории к прототипу.

Многолетнее медийное присутствие королевы означает появление у публики привычки постоянно получать информацию о человеке, который постепенно становится «хорошим знакомым», что отвечает намерениям создателей мифа: быть преданным реальному человеку гораздо проще, чем испытывать лояльность к абстрактной форме правления - монархии.

Та же страница Independent переполнена сообщениями о подробностях жизни королевы, её привычках, окружении, о недавних событиях с её участием, что создаёт в сознании реципиента иллюзию давнего хорошего знакомства с этой персоной:

Queen thanks "those who fought so valiantly" during Second World War (в продолжение темы празднования окончания войны в Европе);

Queen likely to wear mask when she attends church during Balmoral stay;

Captain Tom Moore to be knighted by the Queen at Windsor on Friday;

Queen rides pony in first public appearance since lockdown.

Мифообраз королевы выстраивается с опорой на систему базовых общечеловеческих ценностей, которыми дорожат и британцы: семья, дом, толерантность, безопасность человеческого существования. Так в медийной среде создаётся притягательный образ королевы, в жизни которой приоритетное место отводится семье, детям, заботе о британцах как о собственной семье. Разумеется, подобный образ выстраивается на протяжении достаточно длительного времени в рамках нарративного континуума. В рождественских речах королевы, к которым современные медиа обеспечивают широкий доступ, отражается большинство идей, коррелирующих с ценностными ориентирами британцев, как, например, в следующих фрагментах одного из рождественских выступлений:

\section{After two tragic events in the UK}

In 2017, the year that saw the terror attack in Manchester and Grenfell fire, the Queen reflected on the idea of home in her Christmas Day speech, saying:

- "We think of our homes ${ }^{3}$ as places of warmth, familiarity and love; of shared stories and memories, which is perhaps why at this time of year so many return to where they grew up. There is a timeless simplicity to the pull of home.

- "For many, the idea of "home" reaches beyond a physical building - to a home town or city...

- "We expect our homes to be a place of safety - 'sanctuary' even - which makes it all the more shocking when the comfort they provide is shattered."4 (Queen Elizabeth II Quotes)

\footnotetext{
Здесь и далее подчеркнуто мной - О.К.

4 Qin Xie. Queen Elizabeth II Quotes: 11 of the Monarch’s Best Speeches. Цит. по https://www.independent.co.uk/life-style/royal-family/queenelizabeth-ii-quotes-birthday-speeches-best-moments-a9467021.html. (дата публикации: 21.04.2020; дата обращения: 20.08.2020). (Здесь и далее - Queen Elizabeth II Quotes).
} 
Как было отмечено, нарратив требует правдоподобности, что делает его форматом, чрезвычайно подходящим и даже необходимым для мифотворчества, которое также основано не на правде, но на правдоподобии. Нарративный континуум, несущий информацию о трудностях, с которыми приходится сталкиваться королевской персоне, о критике монархов, о неурядицах в королевской семье, обеспечивает искомую правдоподобность - у монархов тоже есть проблемы, как и у простых людей. Примечательно, что в следующем примере автор прибегает к использованию эмотивной лексики, что призвано усилить впечатление от приведённых фактов и оказать эмоциональное воздействие на аудиторию (to ravage the nation; to weather storms; sudden and tragic death; stoic; wry sense of humour). Воздействующий эффект усиливается благодаря стилистическому приёму градации - перечисление трудностей и горестей королевской жизни даётся по нарастающей: от менее к более серьёзным, от случившихся давно к недавним:

While she has no involvement in politics, the Queen has worked with 14 different Prime Ministers, including Boris Johnson. Former colonies including Ghana and Jamaica have gained independence during her reign, the UK has joined and left the EU, and now the coronavirus pandemic that's ravaging the nation.

In her own family, she has weathered storms too, including the high profile divorce of Prince Charles and Diana, Princess of Wales; the sudden and tragic death of the «People's Princess»; and most recently, Megxit.

Through this, the Queen has remained stoic, often showing her wry sense of humour, seen through her many public addresses and engagements. (Queen Elizabeth II Quotes)

\section{4. Жанровое разнообразие медийного мифотворческого дискурса. «Цитата года»}

Идея стойкости и несгибаемости характера правящей королевы - одна из осевых в её медийном мифообразе - отражается в выборе редакцией «цитаты года», взятой из одной из её рождественских речей и отражающих философское отношение королевы к неприятностям, произошедшим в доме Виндзоров:

\section{The Royals' worst year}

On 24 November 1992, the Queen marked her "annus horribilis" - during which the royal family was marked with scandals from divorce and affairs, to a devastating fire at Windsor Castle - in a speech at Guildhall to mark the 40th anniversary of her Accession. Her majesty reflected:

"I sometimes wonder how future generations will judge the events of this tumultuous year. I dare say that history will take a slightly more moderate view than that of some contemporary commentators. Distance is well-known to lend enchantment, even to the less attractive views. After all, it has the inestimable advantage of hindsight.

«But it can also lend an extra dimension to judgement, giving it a leavening of moderation and compassion - even of wisdom - that is sometimes lacking in the reactions of those whose task it is in life to offer instant opinions on all things great and small." (Queen Elizabeth II Quotes)

В современных медиа, наряду с новостными сообщениями, упоминаниями в статьях и интервью, полнотекстовыми публикациями речей королевы, встречаются целые подборки цитат из выступлений Елизаветы II, которые поддерживают образ монарха, отличающегося заботой о нации, верой в лучшее, стойкостью и бесстрашием (The Queen's most memorable quotes):

\section{Amid the coronavirus pandemic}

In a special address to the UK and the Commonwealth amid the coronavirus pandemic on 5 April 2020, the Queen said:

"While we have faced challenges before, this one is different. This time we join with all nations across the globe in a common endeavour, using the great advances of science and our instinctive compassion to heal. We will succeed - and that success will belong to every one of us. 
"We should take comfort that while we may have more still to endure, better days will return: we will be with our friends again; we will be with our families again; we will meet again." (Queen Elizabeth II Quotes)

Текст приведённого отрывка сфокусирован на будущем и отражает оптимистический взгляд Елизаветы II на перспективы развития ситуации: we will succeed; that success will belong to every one of us; better days will return; we will be with our friends again; we will meet again (Queen Elizabeth II Quotes).

\section{5. Об эмотивной составляющей медийного мифологического дискурса}

Рассмотрение приведённых выше примеров свидетельствует о том, что формирование мифообраза в соответствии с замыслом его разработчиков происходит преимущественно за счёт фактологической информации. Аудитории предоставляется право самостоятельно оценить действия, поступки и высказывания медийного лица, составляющие мифологический нарратив. Другими словами, речь идёт, в основном, об эксплицитной безоценочности мифологического дискурса, что продиктовано фактором адресата - обращением к его системе ценностей, его оценке представленных в медиа действий, поступков, реакций медийной персоны, то есть фактов без эксплицитной эмотивности.

Вместе с тем, эмоциональный посыл, присутствующий в мифологическом нарративе, играет существенную роль, заключающуюся в том, чтобы добавить создаваемому образу человечности, простоты, что сделает образ узнаваемым, похожим на многих, а значит, и его прототип станет понятным и заслуживающим доверия.

Степень эмотивности мифологического нарратива зависит в первую очередь от жанра, тексты которого участвуют в создании мифообраза. Приведённые выше фрагменты нарративного континуума, служащего созданию мифообраза известной медийной персоны, демонстрируют отсутствие эмотивно-оценочного компонента в текстах / заголовках новостных сообщений, имеющих дело с констатацией фактов, в то время как текстам авторских колонок, комментариев, а также обращённых к широкой общественности выступлений самого персонажа, в значительной степени присущи эмотивность и оценочность.

\section{Заключение}

Рассмотрение особенностей мифотворчества в медийной среде показало, что архитектоника медийного мифообраза строится с учётом фактора медийного адресата - его интересов, ценностных ориентиров и моральных устоев, которые учитываются создателями медиа бренда. Ставя в центр повествования медийную персону, разработчики мифа отталкиваются прежде всего от медийных предпочтений аудитории, проявляющей весь спектр эмоциональных состояний - от простого любопытства до восхищения и стремления подражать своему герою. Главная коммуникативная целеустановка создателей мифа-антропонима в медийном пространстве - транслировать информацию, раскрывающую и поддерживающую созданный мифообраз в сознании реципиента. Основным форматом создания мифа в медийном дискурсе является нарратив. Учитывая, что хронотоп мифа может охватывать разные пространства и временные периоды, мы считаем целесообразным говорить о нарративном континууме, представленном рядом историй - повествований о жизни и деятельности медийной персоны. Диахронический аспект мифообраза позволяет создать ощущение стабильности и устойчивости. Исследование мифообраза Елизаветы II в качестве примера подтверждает, что одним из способов медийного мифотворчества является создание эффекта постоянного «присутствия» прототипа мифообраза в информационном пространстве. Так достигается узнаваемость образа и ощущение его приближённости к обычным людям, что заставляет их относиться к королеве как к очень близкому и знакомому человеку и формирует, таким образом, коллективную лояльность. Ориентир на систему ценностей ауди- 
тории диктует выбор определённых личностных качеств королевы, которые подчёркиваются в СМИ. Создание антропонимического мифообраза требует минимум эмотивности в дискурсе и характеризуется эксплицитной безоценочностью, что зависит от медийного жанра, реализующего нарративный континуум, и определяется, в первую очередь, фактором адресата, предполагая обращение к его системе ценностей, на основе которой адресат производит оценку действий, поступков, событий, то есть, предъявленных ему фактов.

Современное масс-медийное пространство хранит как вербальные, так и невербальные свидетельства создания антропонимического медиамифа, что создаёт синергетический эффект, подлежащий отдельному изучению.

(C) Куликова О.В., 2021

\section{Список литературы}

1. Балахонская Ю.В. Отличительные особенности политической мифологии // Вестник Санкт-Петербургского Университета МВД России. 2015 (3 / 67). С. 189 - 194.

2. Балясникова О.В. Исследование речевого воздействия в СМИ // Язык средств массовой информации: Сб.обзоров / РАН.ИНИОН. Центр гуманит. науч.-информ. исслед. Отд.языкознания: Отв.ред. Трошина Н.Н. М., 2007. С. 99 - 112.

3. Водак Р. Язык. Дискурс. Политика / Пер. с англ. и нем. Волгоград: Перемена, 1997. 139 с.

4. Демьянков В.3. Интерпретация политического дискурса в СМИ // Язык средств массовой информации: Учебное пособие для вузов / Под ред. М. Н. Володиной. М.: Академический проект, 2008. С .374-393.

5. Кубрякова Е.С. Эволюция лингвистических идей во второй половине XX века (опыт парадигмального анализа) // Язык и наука конца 20 века: сб. статей. М., 1995. С. 144-238.

6. Моль А. Социолингвистика культуры. М.: КомКнига, 2005. 416 с.

7. Пастухов А.Г. Медиажанры и медиаформаты: к разграничению понятий // Учёные записки Орловского государственного университета. Сер.: Гуманитарные и социальные науки. 2015(5 / 68). С. 148 - 153.

8. Политические коммуникации: Учеб. пособие для студентов вузов / Петрунин Ю.Ю. и др. Под ред. А.И. Соловьева. М.: Аспект Пресс. 2004. 332 с.

9. Христова Н.А. Деструкция конвенционального стереотипа «власть»: (На материале медиатекстов) // Языковое сознание и культура. М., 2005. С. 155 - 163.

10. Шейгал Е.И. Семиотика политического дискурса. М.: ИТДГК «Гнозис», 2004. 326 с.

11. Шмид В. Перспективы и границы когнитивной нарратологии (По поводу работ Алана Пальмера о «fictional mind» и «social mind») // Электронный журнал «Нарраториум». 2014, 2014 №1 (7). URL: http://narratorium.rggu.ru/article. html?id=2633109

12. Bruner 2003. The Narrative Construction of Reality.

13. Chafe W.L. The flow of thought and the flow of language // Syntax and Semantics: Discourse and Syntax / Ed. by Talmy Givon. Vol. 12, Academic Press, 1979. P. 159 - 182.

14. Labov, W. Speech actions and reactions in personal narrative. Georgetown University roundtable on languages and linguistics, 1981. P. 219-247.

\section{References}

1. Balahonskaya, Yu.V. Otlichitel'nye osobennosti politicheskoi mifologii // Vestnik Sankt-Peterburgskogo Universiteta MVD Rossii. 2015 (3 / 67). S. 189 - 194.

2. Balyasnikova, O.V. Issledovanie rechevogo vozdeistviia v SMI // Iazyk sredstv massovoj informatsii: Sb.obzorov / RAN.INION. Tsentr gumanit. nauch.-inform. issled. Otd.iazykoznaniia: Otv.red. Troshina N.N. M., 2007. S. 99 - 112.

3. Vodak, R. Iazyk. Diskurs. Politika / Per. s angl. i nem. Volgograd: Peremena, 1997. 139 s.

4. Dem'yankov, V.Z. Interpretatsiia politicheskogo diskursa v SMI // Iazyk sredstv massovoi informatsii: Uchebnoe posobie dlia vuzov / Pod red. M. N. Volodinoi. M.: Akademicheskii proekt, 2008. S.374-393.

5. Kubryakova, E.S. Evoliutsiia lingvisticheskikh idei vo vtoroi polovine XX veka (opyt paradigmal'nogo analiza) // Iazyk i nauka kontsa XX veka: sb. statei. M. 1995. S. 144-238.

6. Mol', A. Sotsiolingvistika kul'tury. M.: KomKniga, 2005. $416 \mathrm{~s}$.

7. Pastuhov, A.G. Mediazhanry i mediaformaty: k razgranicheniiu poniatii // Uchenye zapiski Orlovskogo gosudarstvennogo universiteta. Ser.: Gumanitarnye i social'nye nauki. 2015(5 / 68). S. 148 - 153.

8. Politicheskie kommunikatsii: Ucheb. posobie dlia studentov vuzov / Petrunin Yu.Yu. i dr. Pod red. A.I. Solov'eva. M.: Aspekt Press. 2004.332 s.

9. Hristova, N.A. Destruktsiia konventsional'nogo stereotipa «vlast'»: (Na materiale mediatekstov) // Iazykovoe soznanie $i$ kul'tura. M., 2005. S. 155 - 163.

10. Sheigal, E.I. Semiotika politicheskogo diskursa. M.: ITDGK «Gnozis», 2004. 326 s. 
11. Shmid, V. Perspektivy i granitsy kognitivnoi narratologii (Po povodu rabot Alana Pal'mera o «fictional mind» $\mathrm{i}$ «social mind») // Elektronny zhurnal «Narratorium». 2014, 2014 №1 (7), narratorium.rggu.ru/article.html?id=2633109

12. Bruner 2003. The Narrative Construction of Reality.

13. Chafe, W.L. The flow of thought and the flow of language // Syntax and Semantics: Discourse and Syntax / Ed. by Talmy Givon. Vol. 12, Academic Press, 1979. P. 159 - 182.

14. Labov, W. Speech actions and reactions in personal narrative. Georgetown University roundtable on languages and linguistics, 1981. P. 219-247.

\section{Сведения об авторе:}

Куликова Ольга Викторовна - доктор филологических наук, доцент, профессор кафедры английского языка №1 МГИМО МИД России, научная специализация: 10.02.04 «Германские языки».

E-mail: ok517@yandex.ru

\section{About the author:}

Kulikova Olga Viktorovna - Doctor of Philology, Professor, English Language Department №1 Moscow State Institute of International Relations (University). E-mail: ok517@yandex.ru 